\title{
Supplemental Data on PCB Paint at the U.S. Department of Energy Savannah River Site
}

by

N. J. Lowry

Westinghouse Savannah River Company

Savannah River Site

Aiken, South Carolina 29808

B. L. Westover

R. Koenig

D. M. Nichols

\author{
RECEIVF! \\ JUL 26 Q \\ OST1
}

This paper was prepared in connection with work done under the above contract number with the U.S. Department of Energy. By acceptance of this paper, the publisher and/or recipient acknowledges the U.S. Government's right to retain a nonexclusive, royalty-free license in and to any copyright covering this paper,

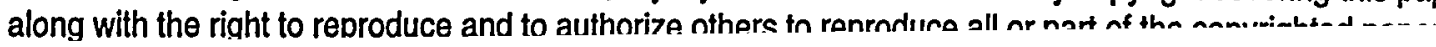




\section{DISCLAIMER}

This report was prepared as an account of work sponsored by an agency of the United States Government. Neither the United States Government nor any agency thereof, nor any of their employees, makes any warranty, express or implied, or assumes any legal liability or responsibility for the accuracy, completeness, or usefulness of any information, apparatus, product, or process disclosed, or represents that its use would not infringe privately owned rights. Reference herein to any specific commercial product, process, or service by trade name, trademark, manufacturer, or otherwise does not necessarily constitute or imply its endorsement, recommendation, or favoring by the United States Government or any agency thereof. The views and opinions of authors expressed herein do not necessarily state or reflect those of the United States Government or any agency thereof.

This report has been reproduced directly from the best available copy.

Available to DOE and DOE contractors from the Office of Scientific and Technical Information, P.O. Box 62, Oak Ridge, TN 37831; prices available from (615) 576-8401.

Available to the public from the National Technical Information Service, U.S. Department of Commerce, 5285 Port Royal Road, Springfield, VA 22161. 


\section{DISCLAIMER}

Portions of this document may be illegible in electronic image products. Images are produced from the best available original document. 


\title{
SUPPLEMENTAL DATA ON PCB PAINT
}

\author{
AT THE U. S. DEPARTMENT OF ENERGY \\ SAVANNAH RIVER SITE
}
Westinghouse Savannah River Company
Savannah River Site

June 10, 1999 
WSRC-TR-99-00194

SUPPLEMENTAL DATA ON PCB PAINT

AT THE U. S. DEPARTMENT OF ENERGY

SAVANNAH RIVER SITE

Authors:

Yancy fancy Lowry

Date: $6-10-99$

Environmental Protection Department

Environment, Safety, Health and Quality Assurance Division

Betzon Swestover Date:

$6-10-99$

Betsy L.G Westover

Regulatory Programs Section

Spent Fuel Storage Division

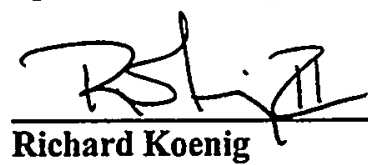

Date: $6-10-99$

Reactor Operations Department

Spent Fuel Storage Division

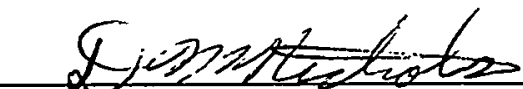

Date: 6.10.99

David M. Nichols

Regulatory Programs Section

Spent Fuel Storage Division 
WSRC-TR-99-00194

\section{SUPPLEMENTAL DATA ON PCB PAINT}

\section{AT THE U. S. DEPARTMENT OF ENERGY, SAVANNAH RIVER SITE}

\section{Purpose of Report:}

As reported to the EPA on previous occasions, the Savannah River Site (SRS) has detected polychlorinated biphenyls (PCBs) in certain applied paints. PCBs have been detected in various special purpose paints applied in certain older site facilities prior to the PCB ban imposed by the Toxic Substances Control Act (TSCA) and its implementing regulations. In response to an EPA request call for data, SRS submitted information on PCBs in paint to EPA-HQ on two previous occasions (references 1 and 2). The purpose of this document is to provide EPA Headquarters with additional analytical data on the presence of PCBs in painted surfaces. The activities reported herein, including sample collection, were conducted by the Westinghouse Savannah River Company (WSRC), which is the management and integrating contractor for the DOE at SRS.

\section{Description of Sampling Effort:}

In the latter part of 1998 , significant concentrations of PCBs were detected in the painted surfaces of one of the SRS production nuclear reactor facilities. The facility was constructed in the 1950 s. The PCBs were detected during preparation for an extensive renovation of the facility. The facility, when renovated, will be used for secure storage of several tons of plutonium in support of the DOE's nuclear non-proliferation efforts.

PCBs were detected in the paint on a variety of items, including equipment, floors and walls. Many of these items have been or will be disposed in an on-site low-level radioactive waste disposal facility. However, continued use of the floor and walls of this large facility was necessary. Due to radiological concerns, disturbance of these painted surfaces, other than the minimum amount necessary to accomplish the renovation, was highly undesirable.

WSRC assessed the condition of the paint on surfaces that were not to be disposed. Visual inspection revealed that most of the paint was in good condition. Some areas of the floor paint, which had been subjected to the most wear over the years, were in poor condition. SRS then conducted hexane wipe tests on the painted surfaces.

\section{Analytical Results:}

In the majority of cases, the PCB concentrations in wipe samples were determined to be well below ten micrograms per wipe of a $100 \mathrm{~cm}^{2}$ surface area, i.e., $<10 \mathrm{ug} / 100 \mathrm{~cm}^{2}$. This was true even for paint with greater than $1 \%$ PCBs. In only two instances did the wipe samples show PCB concentrations above 10$\mathrm{ug} / 100 \mathrm{~cm}^{2}$; both of those samples were of the degraded floor paint.'

Previous analytical testing has led WSRC to believe that, when the paint is in good condition, PCBs tend to remain bound up in the paint matrix and do not pose a dermal exposure hazard. Wipe testing of intact paint in good condition has revealed PCBs to be $<10 \mathrm{ug} / 100 \mathrm{~cm}^{2}$. However, wipe samples of degraded paint have exceeded $10 \mathrm{ug} / 100 \mathrm{~cm}^{2}$. The most recent SRS data reported herein is consistent with this trend. A summary of the data pertaining to this project is provided as Enclosure 1, along with photographs of many

\footnotetext{
' Based on its assessment, SRS took steps to encapsulate the floor paint with two coats of sealant-type paint in contrasting colors. The walls, up to a height of 12 feet, also have been encapsulated to provide a protective barrier for personnel (personnel access will be infrequent once the plutonium is received). The walls and floor have been marked with the EPA large PCB mark.
} 
of the sample locations (Enclosure 2). Provided as Enclosures 3 and 4.are copies of the sample plans that were used.

\section{Recommendations:}

WSRC recommends to DOE and EPA, that EPA authorize the continuing use of intact PCB paints and coatings that do not pose an unreasonable risk to human health or the environment. WSRC recommends the use of the standard wipe test to determine whether a particular coating poses a risk. WSRC also recommends that EPA prescribe appropriate mitigating actions for paints that do represent a hazard. WSRC recommends that authorization requirements be self-implementing to the maximum possible extent. Both non-porous surfaces and porous surfaces such as painted concrete should be addressed. WSRC strongly recommends that EPA include a mechanism through which PCB coatings can be managed in a manner other than by complete paint removal, e.g., by encapsulation. WSRC also recommends that EPA include a risk-based approval process to address unusual or complex situations, such as the presence of radioactivity.

\section{References:}

1. "Analytical Study of High Concentration PCB Paint at the Heavy Water Components Test Reactor (HWCTR)", WSRC-TR-98-00374, October 5, 1998

2. Letter, J.V. Odum, WSRC to Winston A. Smith, EPA Region 4, "Request for an Enforcement

Discretion Letter (U)", ESH-FSS-97-0050, February 14, 1997.

\section{Enclosures:}

1. Chart, "KAMS Project Paint PCB/Wipe Results", Prepared April 6, 1999.

2. Photographs of sample locations and room in which samples were collected.

3. "Sample \& Analysis Plan for the Characterization of Polychlorinated Biphenyls (PCB) Materials", SFS-RPS-980075, Revision 1, November 17, 1998.

4. "Sample \& Analysis Plan for the Characterization of Polychlorinated Biphenyls (PCB) and Resource Conservation and Recovery Act (RCRA) Materials", SFS-RPS-980133, November 13, 1998. 


\begin{tabular}{|c|c|c|c|c|c|c|c|c|}
\hline $\begin{array}{c}\text { Bulk Sample } \\
\text { Number }\end{array}$ & Bulk Sample Location & Paint Color & $\begin{array}{c}\text { PCB result } \\
\text { (bulk) }\end{array}$ & $\begin{array}{c}\text { PCB result } \\
\text { (bulk) }\end{array}$ & $\begin{array}{c}\text { Wipe } \\
\text { Sample } \\
\text { No. } \\
\end{array}$ & Wipe Sample Location & $\begin{array}{c}\text { PCB Wipe } \\
\text { resalt }\end{array}$ & $\begin{array}{c}\text { Detection } \\
\text { Limit (wipe } \\
\text { samples) }\end{array}$ \\
\hline & & & $(u g / k g)$ & $(\mathrm{mg} / \mathrm{kg})=\mathrm{ppm}$ & & & (ug/smear) & (ug) \\
\hline $98160-1 / 98250-1$ & Presentation Point Platform & gray & 1050000 & 1050 & & & & \\
\hline $98250-2$ & Process Room Floor & bluegreen & 2750000 & 2750 & $98402-5$ & Process Room Floor & 7.2 & 0.50 \\
\hline $98250-3$ & Process Room Floor & bluegreen & 3500000 & 3500 & & & & \\
\hline $98250-4$ & Process Room Floor & bluegreen & 4590000 & 4590 & & & & \\
\hline $98250-5$ & Process Room Floor & bluegreen & 4340000 & 4340 & $98402-8$ & Process Room Floor & 19.6 & 1.00 \\
\hline $98250-6$ & Process Room Wall & white & 9010000 & 9010 & $98402-4$ & Process Room Wall & 0.28 & 0.10 \\
\hline $98250-7$ & Process Room Wall & white & 19500000 & 19500 & & & & \\
\hline $98250-8$ & Process Room Wall & white & 13700000 & 13700 & & & & \\
\hline $98250-9$ & Process Room Wall & white & 15000000 & 15000 & $98402-2$ & Process Room Wall & 0.163 & 0.10 \\
\hline $98250-10$ & Black Stripes at D\&E Canal & black & 9370000 & 9370 & & & & \\
\hline $98250-11$ & Crane Rinse Tank (CRT) & NA & NA & NA & & & & \\
\hline $98250-12$ & Stairs in CMA (1st stringer on right side) & lightgreen & 1220000 & 1220 & & & & \\
\hline $98250-13$ & Safety Rod Thimble & gray & 14900 & 14.9 & & & & \\
\hline $98250-14$ & Crane Wash Area, left side, structure & gray & 392000 & 392 & & & & \\
\hline $98250-15$ & Grating at sump in Presentation Area & yellow & 44400 & 44.4 & & & & \\
\hline $98250-16$ & CMA floor & red & 4600000 & 4600 & $98402-7$ & CMA Floor (Red) & 5.28 & 0.40 \\
\hline $98250-17$ & Inner Shield Door Process Room side & white & 7890000 & 7890 & 98402-1 & Inner Shield Door Process Room Side & 0.163 & 0.10 \\
\hline $98250-18$ & Inner Shield Door Crane Wash side & white & 4210000 & 4210 & $98402-6$ & Inner Shield Door CMA Side & 3.65 & 0.40 \\
\hline $98250-19$ & Outer Shield Door, Process Room side & white & 3650000 & 3650 & $98402-10$ & Outer Shield Door Process Room Side & 0.265 & 0.10 \\
\hline $98250-20$ & Spray System, Process Room & gray & 51900 & 51.9 & & & & \\
\hline $98250-21$ & Spray System, Process Room, Air Actuator & green & 121000 & 121 & & & & \\
\hline $98250-22$ & Charge Machine & gray & 100000 & 100 & & & & \\
\hline $98377-1$ & Donning \& Doffing Area (CMA) & white & 6350 & 6.35 & & & & \\
\hline $98377-2$ & RCO Lab & white & 6200 & 6.2 & & & & \\
\hline $98377-3$ & CMA floor (between stack area and CMA) & yellow & 80400 & 80.4 & $98402-9$ & CMA Floor Yellow & 24.6 & 2.00 \\
\hline $98377-4$ & Oxalic Acid Structure & green & 546 & 0.546 & & & & \\
\hline $98377-5$ & Oxalic Acid Structure & gray & 6300 & 6.3 & & & & \\
\hline $98377-6$ & Inner Shield Door, Process Room & white & No result & No result & & & & \\
\hline $98377-7$ & Inner Shield Door, Crane Wash & white & 3400000 & 3400 & & & & \\
\hline 98377.8 & Outer Shield Door, Crane Wash & white & No result & No result & & & & \\
\hline $98377-9$ & Kanne Hose Line & purple/white & 1520 & 1.52 & & & & \\
\hline & & & & & $|98402-11|$ & Outer Shield Door CMA Side & $0327+3>150$ & 010 \\
\hline & & & & & $98402-3$ & Process Room Wall (D\&E) & 0.23 & 0.10 \\
\hline
\end{tabular}




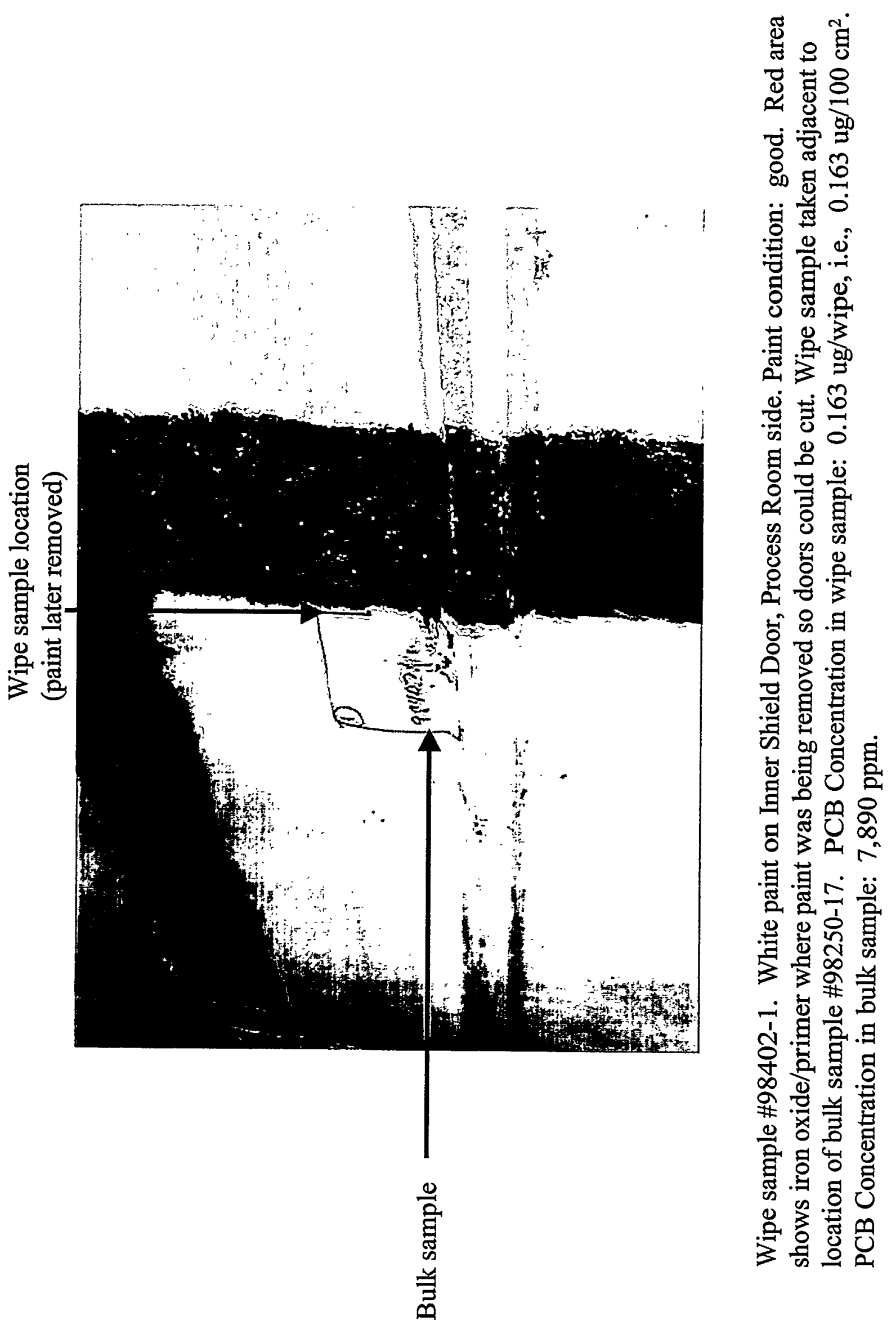




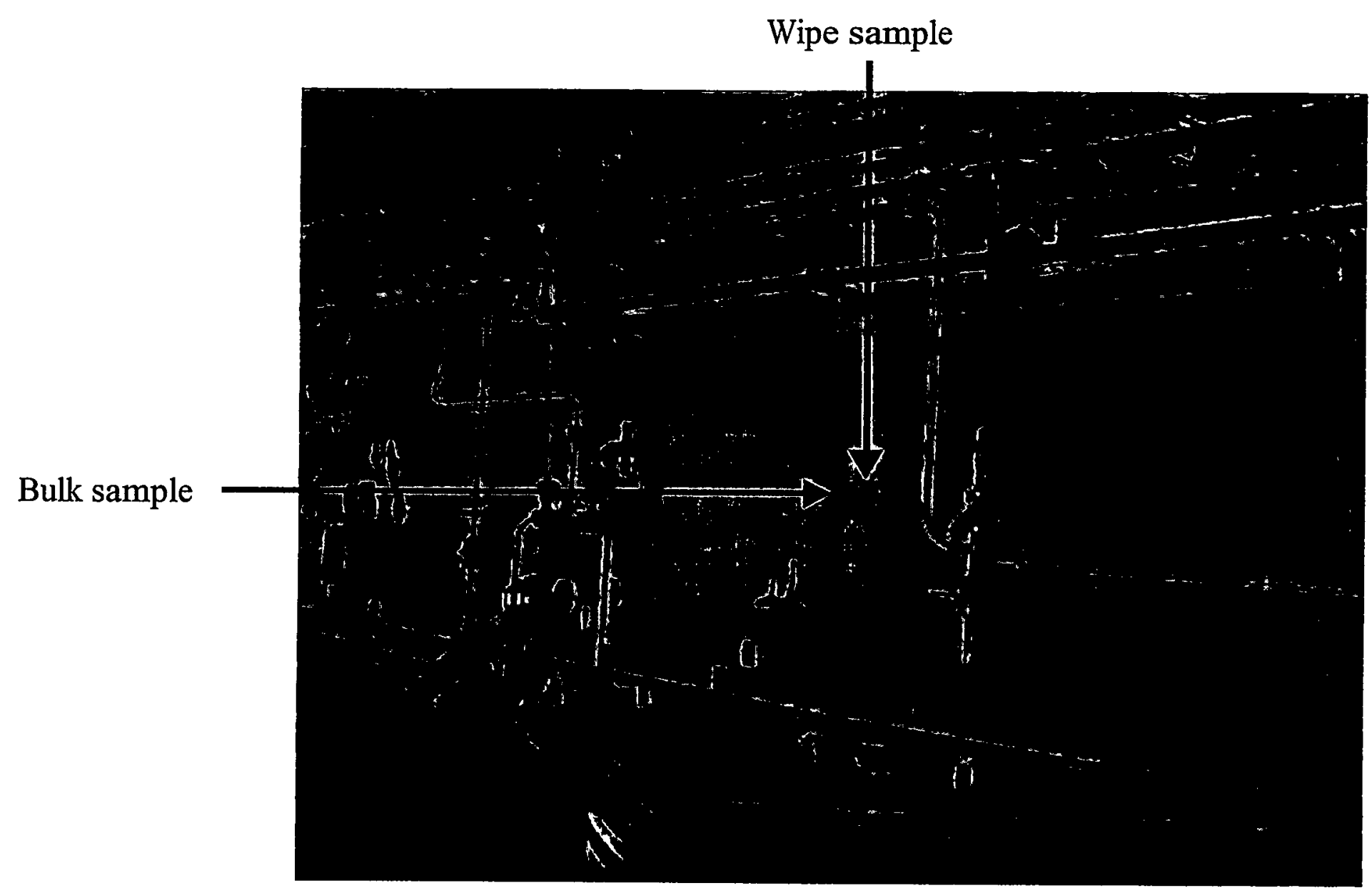

Wipe sample \#98402-2, White paint on process room wall. Paint condition: good. Wipe sample taken close to location of bulk sample \#98250-9. PCB concentration in wipe sample: $0.163 \mathrm{ug} /$ wipe, i.e. $0.163 \mathrm{ug} / 100 \mathrm{~cm}^{2}$. PCB concentration in bulk sample: $15,000 \mathrm{ppm}$. 


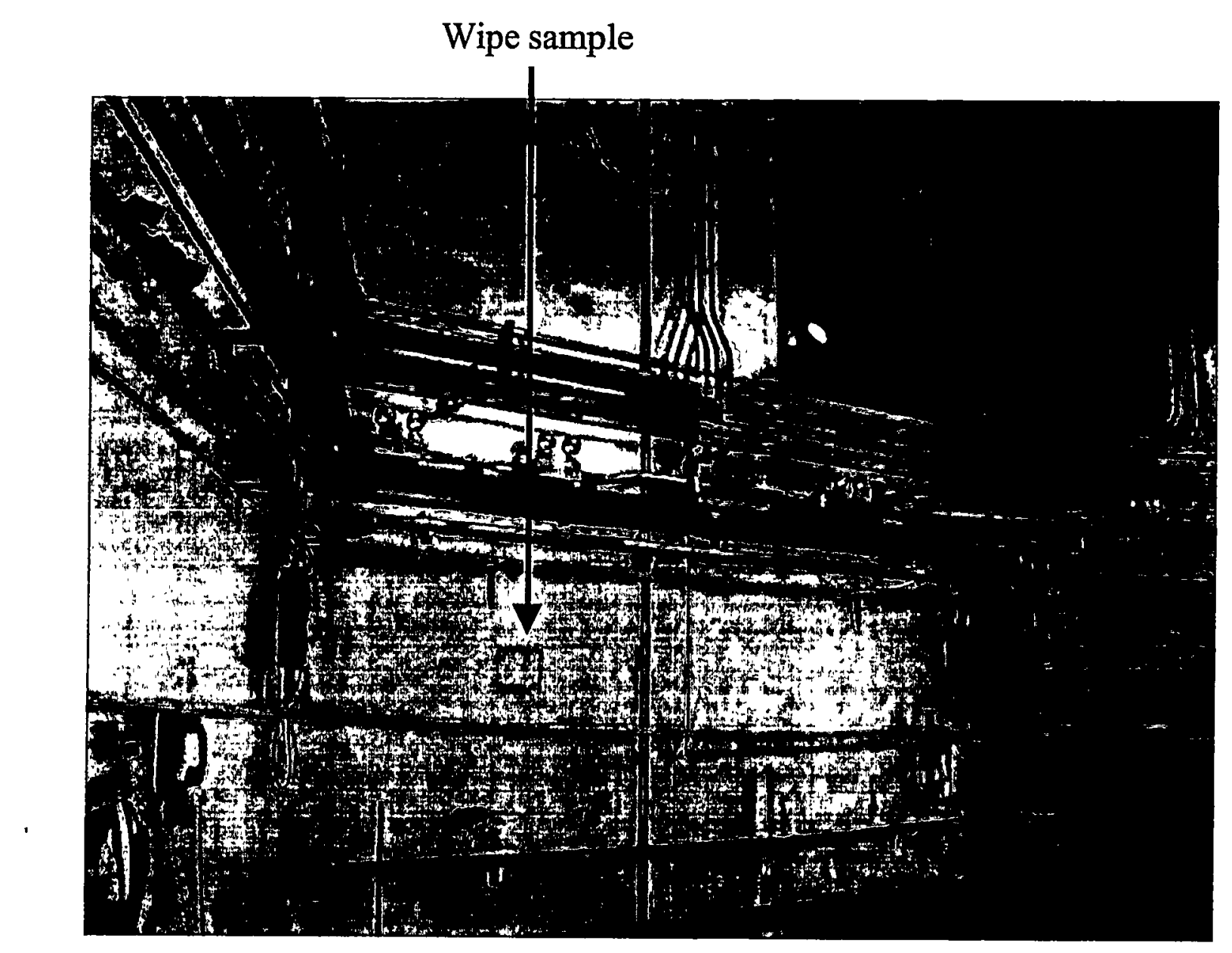

Wipe sample \#98402-3, White paint on wall of process room. Paint condition: good. No bulk sample from immediate vicinity (closest was $98250-9$ ). PCB concentration in wipe sample: $0.23 \mathrm{ug} /$ wipe, i.e. $0.23 \mathrm{ug} / 100 \mathrm{~cm}^{2}$. PCB concentration in bulk sample $98250-9$ was 15,000 ppm. 


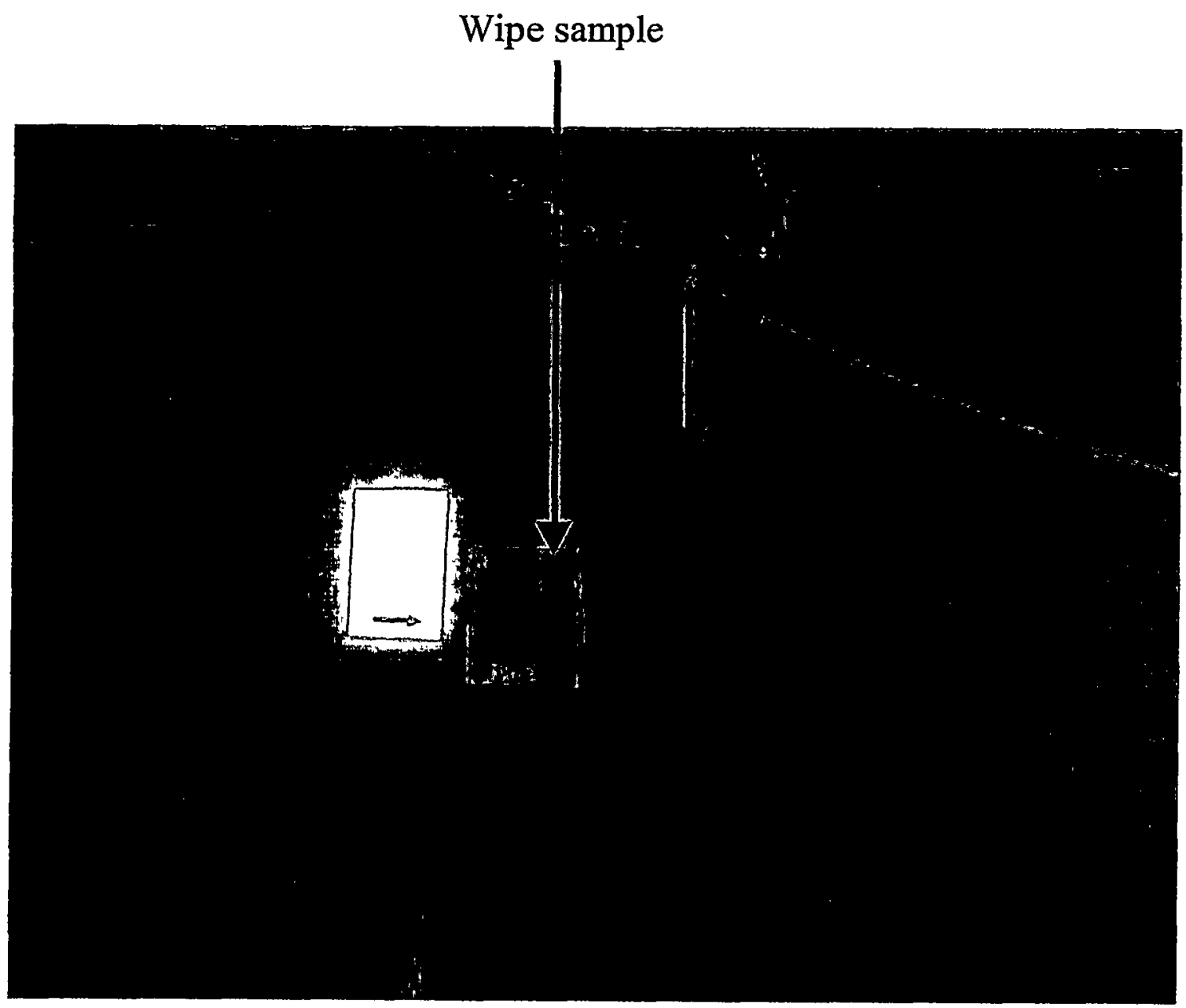

Wipe sample \#98402-4, White paint on process room wall. Paint condition: good. Wipe sample taken in vicinity of bulk sample \#98250-6. PCB concentration in wipe sample: $0.28 \mathrm{ug} /$ wipe, i.e. $0.28 \mathrm{ug} / 100 \mathrm{~cm}^{2}$. PCB concentration in bulk sample $=9,010 \mathrm{ppm}$. 


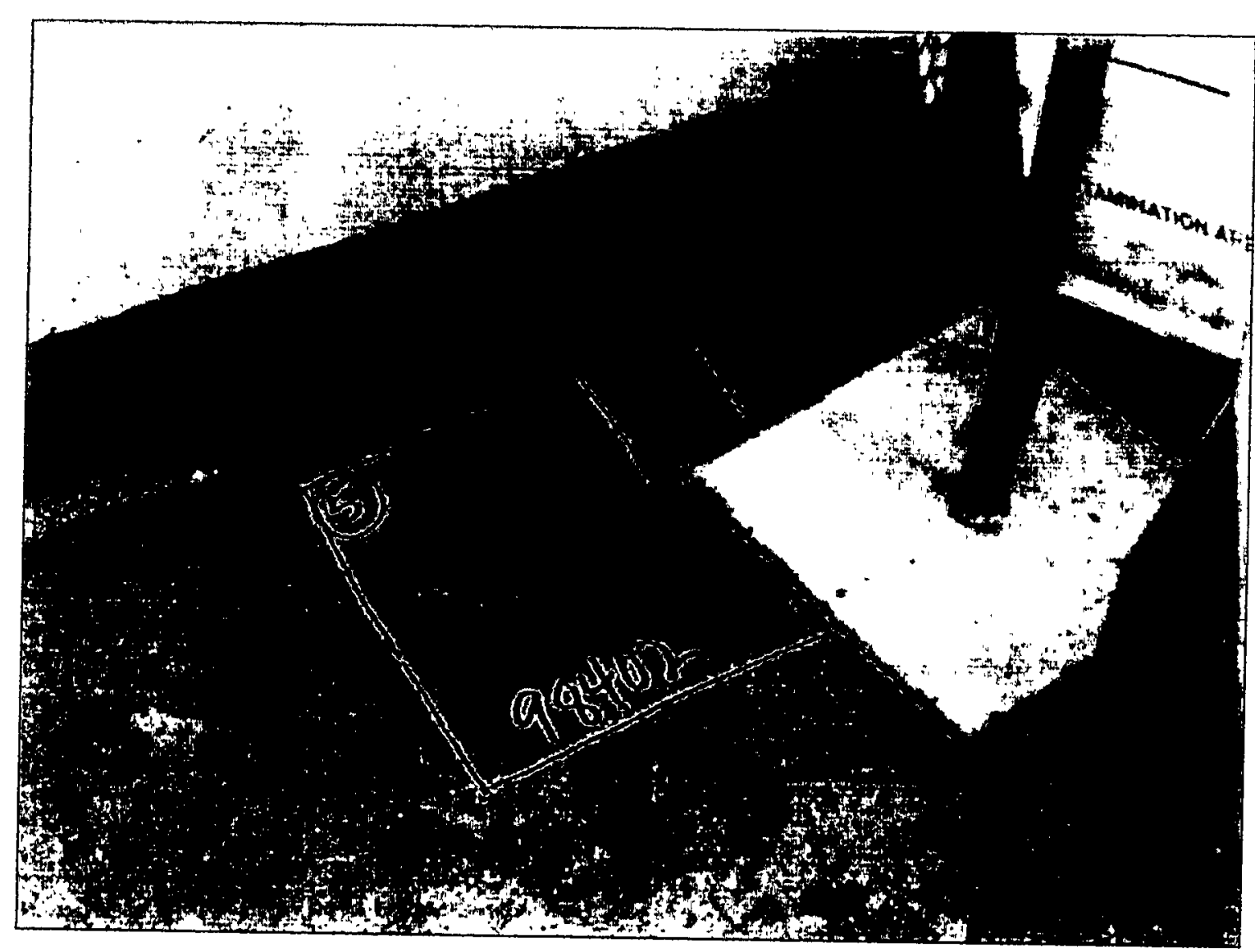

Wipe sample \#98402-5, Bluegreen paint on process room floor. Paint condition: variable; worn in high traffic areas and fair in others. Wipe sample taken close to location of bulk sample \#98250-2. PCB concentration in wipe sample: $7.2 \mathrm{ug} /$ wipe, i.e. $7.2 \mathrm{ug} / 100 \mathrm{~cm}^{2}$. PCB concentration in bulk sample $=2,750 \mathrm{ppm}$. 
Bulk sample

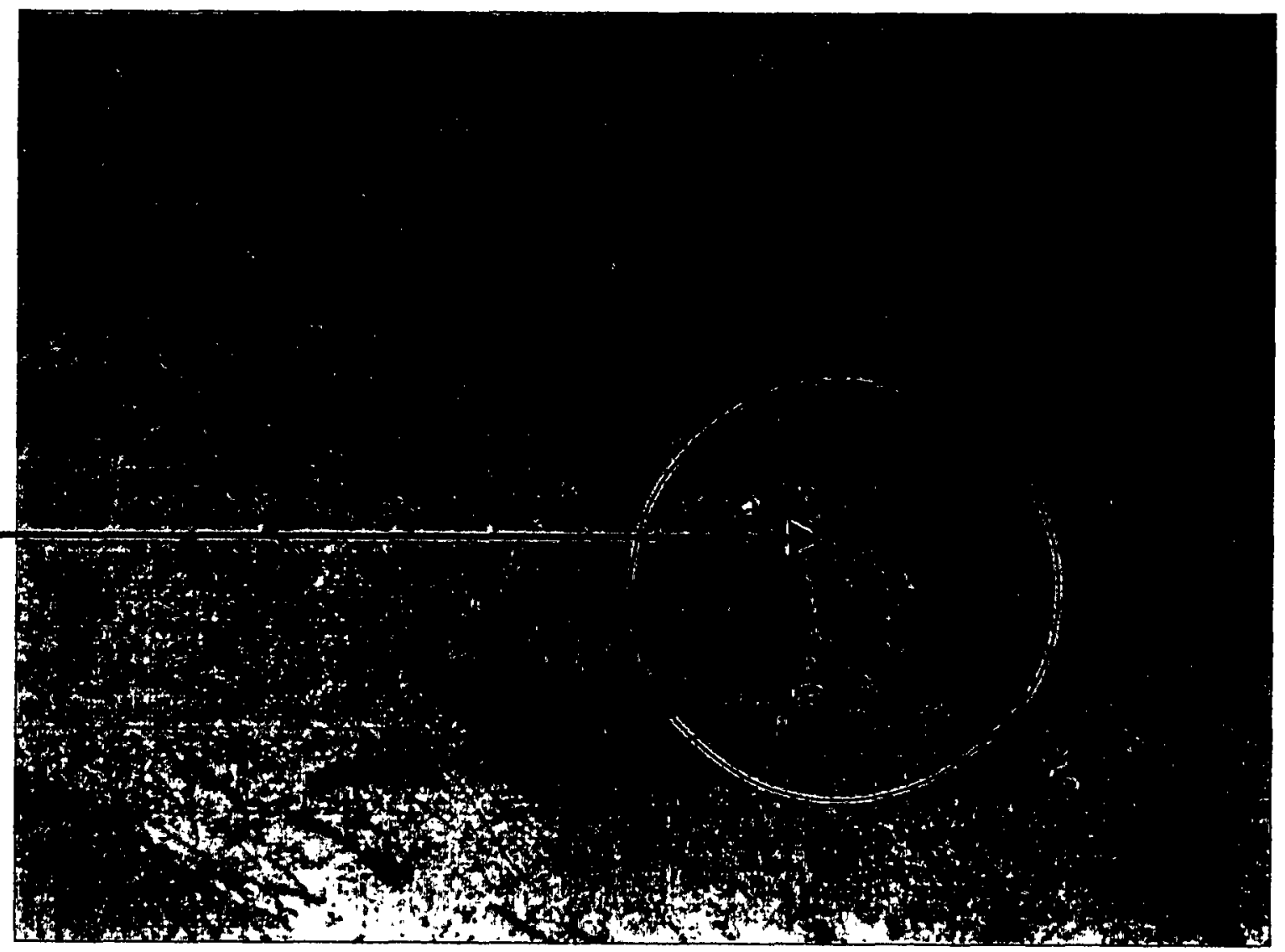

Location of bulk paint sample \#98250-2, Bluegreen paint on process room floor. Paint condition: poor. Bulk sample taken in vicinity of wipe sample $98402-5$. PCB concentration in wipe sample 98402-5: $7.2 \mathrm{ug} / \mathrm{wipe}$, i.e. 7.2 $\mathrm{ug} / 100 \mathrm{~cm}^{2}$. PCB concentration in bulk sample $=2,750 \mathrm{ppm}$. Another wipe sample of floor, \#98402-8, was taken (photo not available) with a result of $19.6 \mathrm{ug} / 100 \mathrm{~cm}^{2}$. 


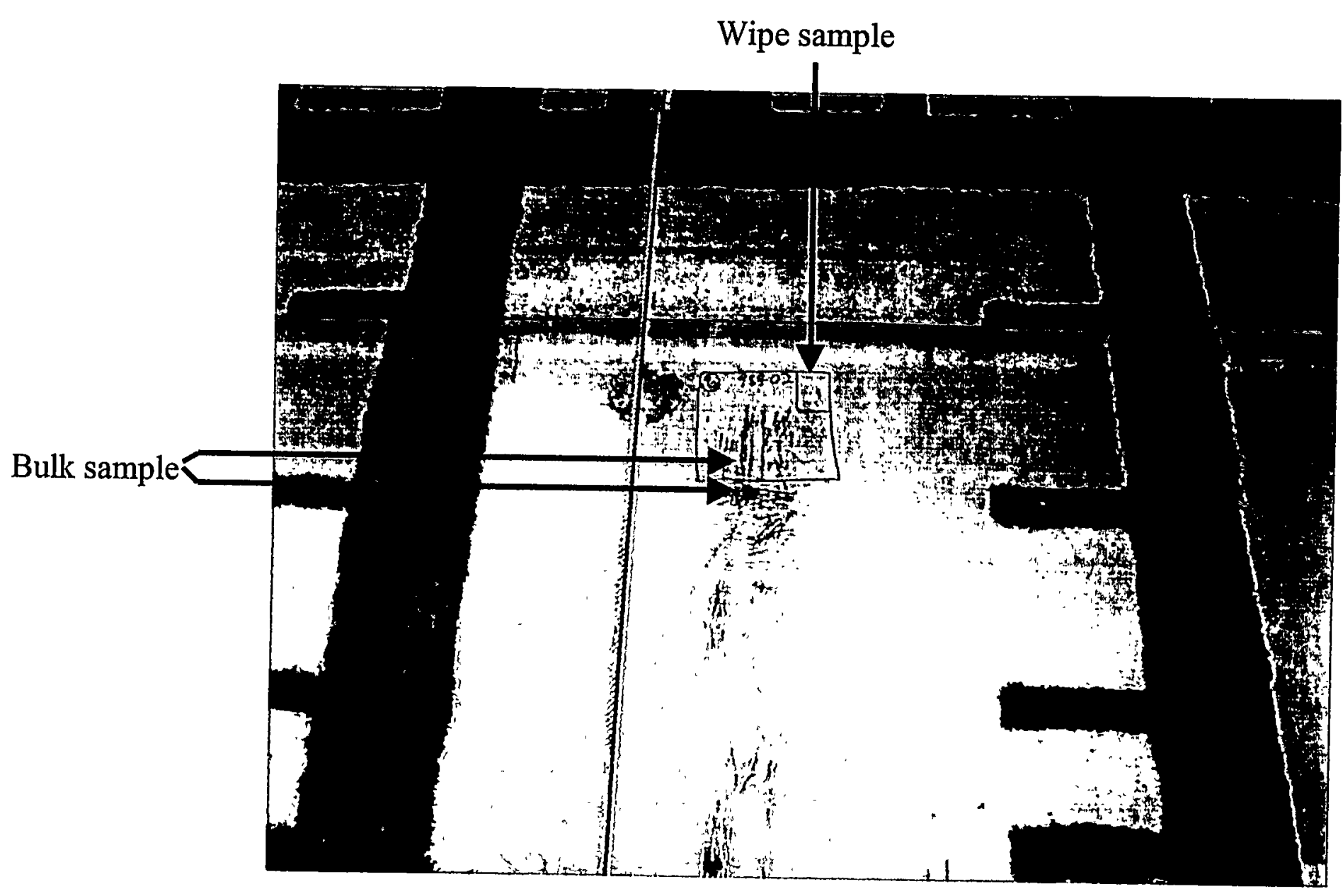

Wipe sample \#98402-6. White paint on Inner Shield Door, Crane Wash Side. Paint condition: good. Wipe sample taken close to location of bulk sample \#98250-18. PCB concentration in wipe sample: $3.65 \mathrm{ug} / \mathrm{wipe}$ i.e., $3.65 \mathrm{ug} /$ $100 \mathrm{~cm}^{2}$. PCB concentration in bulk sample $=4,210 \mathrm{ppm}$. (Dark areas are where paint was being removed prior to
cutting steel doors.) 


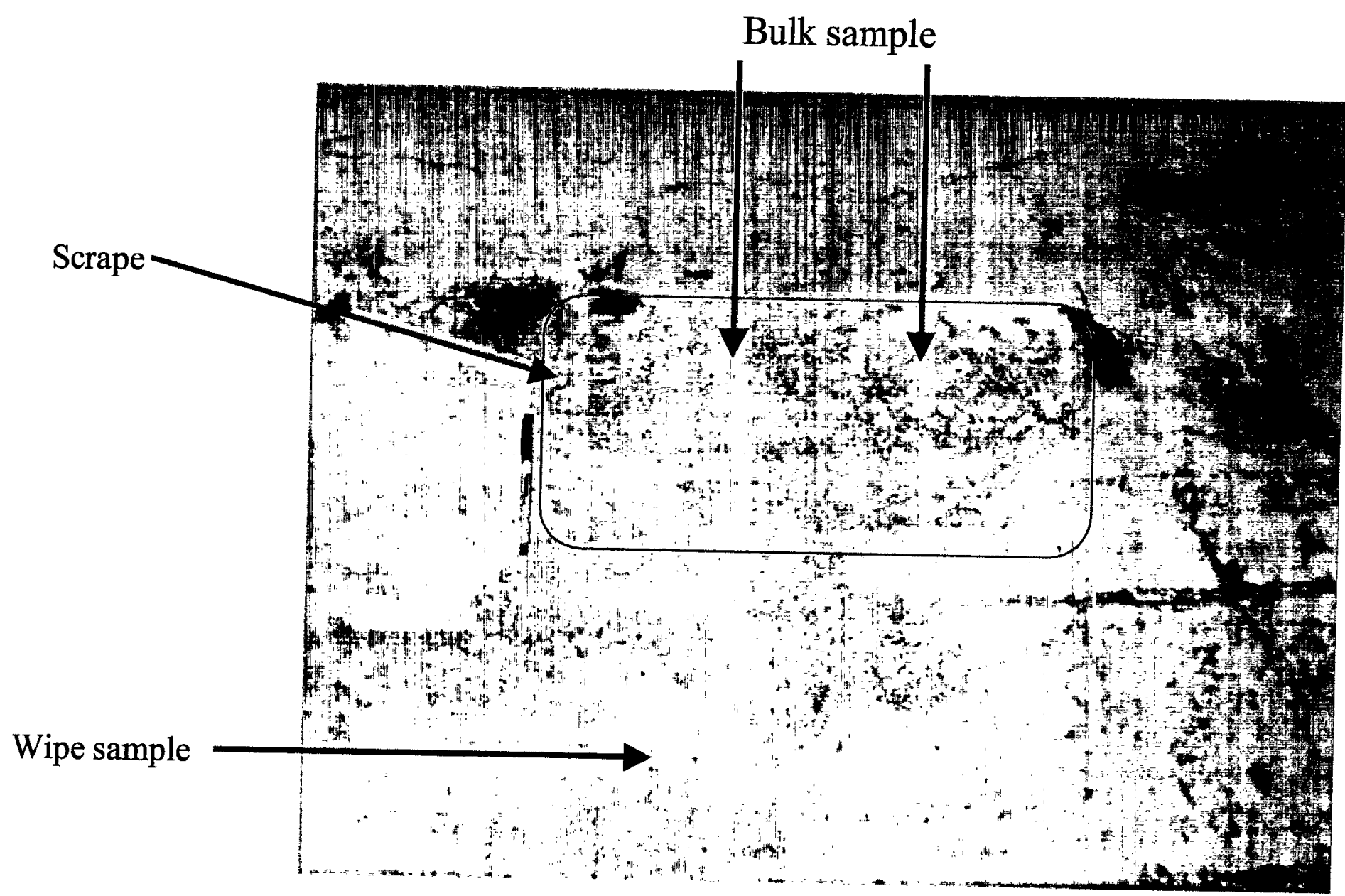

Wipe sample \#98402-9. Yellow paint on crane maintenance area floor. Paint condition: poor. Wipe sample taken close to location for bulk sample \#98377.3. PCB concentration in wipe sample: $24.6 \mathrm{ug} / \mathrm{wipe}$, i.e., $24.6 \mathrm{ug} / 100 \mathrm{~cm}^{2}$. PCB concentration in bulk sample $=80.4 \mathrm{ppm}$. Pen is size reference of scrape spot, smear was taken in the vicinity
of shiny area below pen. 


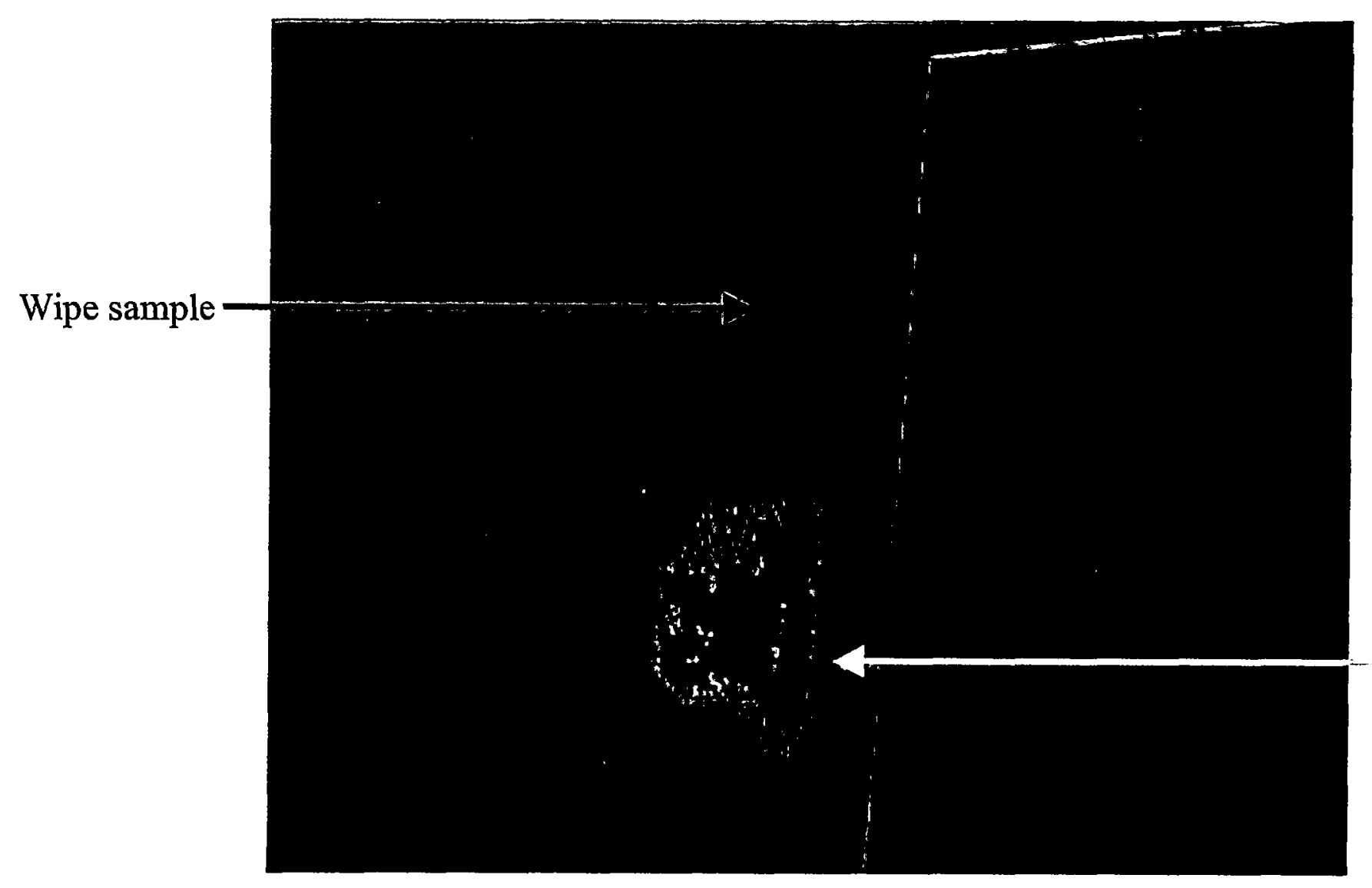

Bulk sample

Wipe sample \#98402-10 taken near location of bulk sample \#98250-19. White paint on outer shield door on process room side. Paint condition: good. PCB concentration in wipe sample: $0.265 \mathrm{ug} / \mathrm{wipe}$, i.e., 0.265 $\mathrm{ug} / 100 \mathrm{~cm}^{2}$. PCB concentration in bulk sample: $3,650 \mathrm{ppm}$ PCB. 
Wipe sample

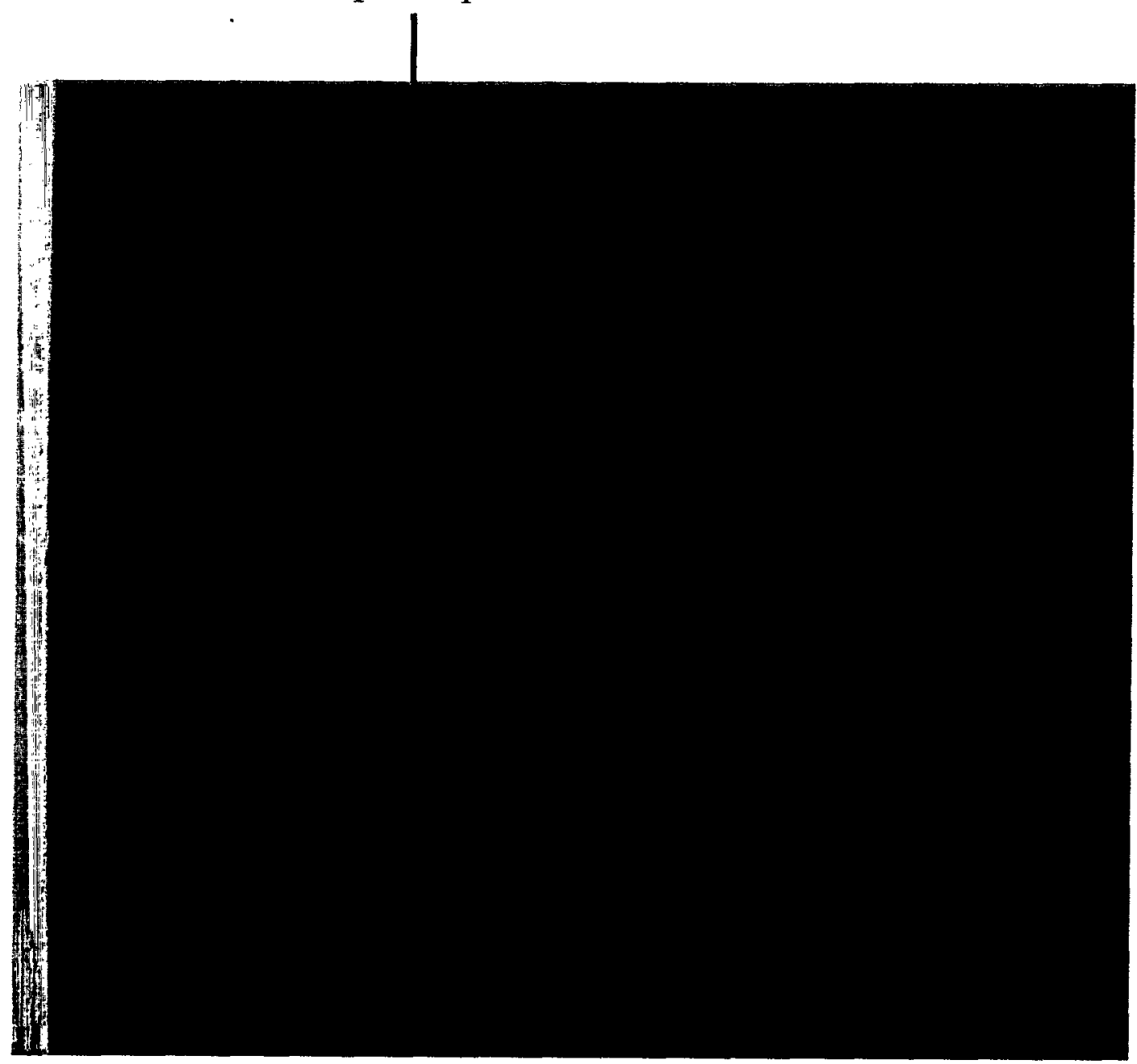

Wipe sample \#98402-11 taken near Crane Maintenance Area (CMA) side of outer shield door. No bulk sample collected on CMA side of door. Bulk sample \#98250-19 was collected on opposite side of door (believed to be same paint) and had 3,650 ppm PCBs. PCB concentration in wipe sample: $0.327 \mathrm{ug} /$ wipe, i.e., $3.27 \mathrm{ug} / \mathrm{cm}^{2}$. 

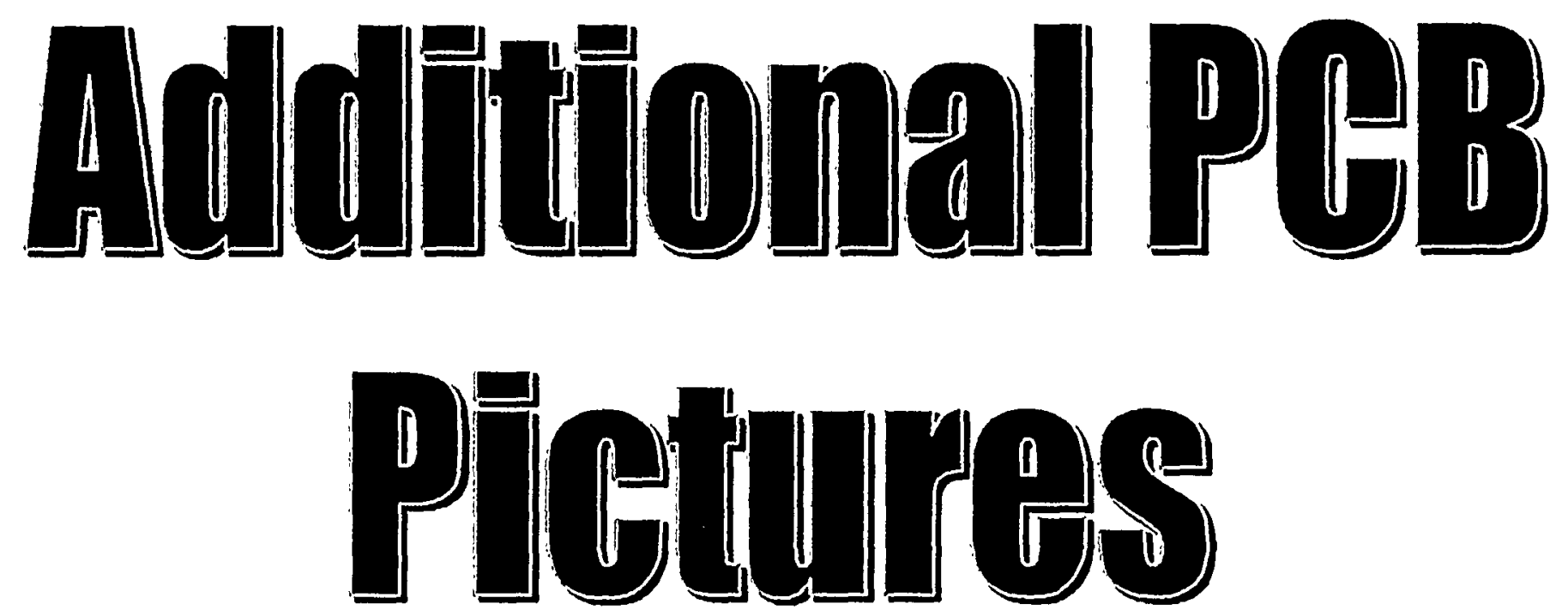


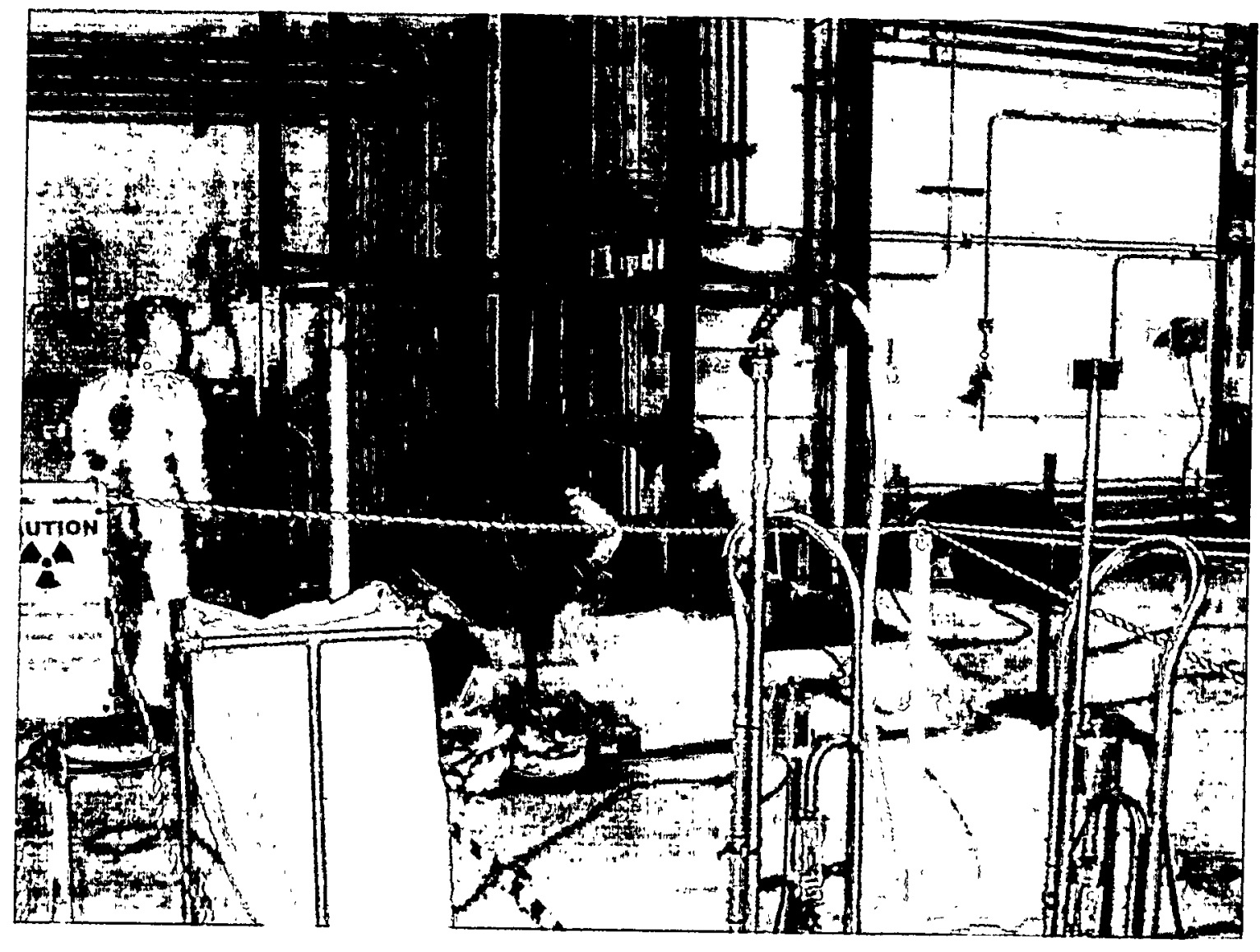

View of presentation point structure platform (gray, 1050 ppm). Sample Job 98250. 


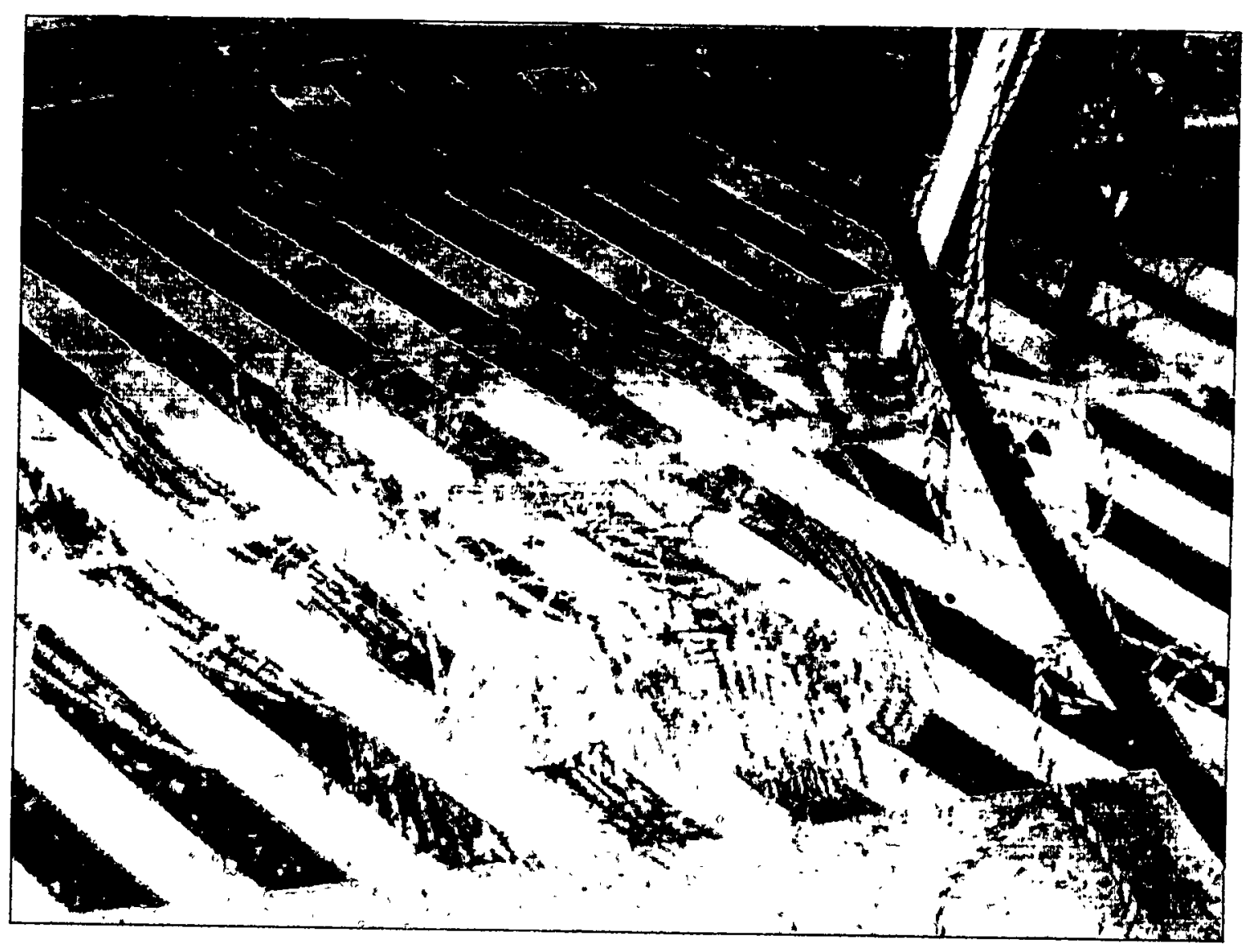

View of black stripes at D\&E canal (9,370 ppm), Sample Job 98250. 


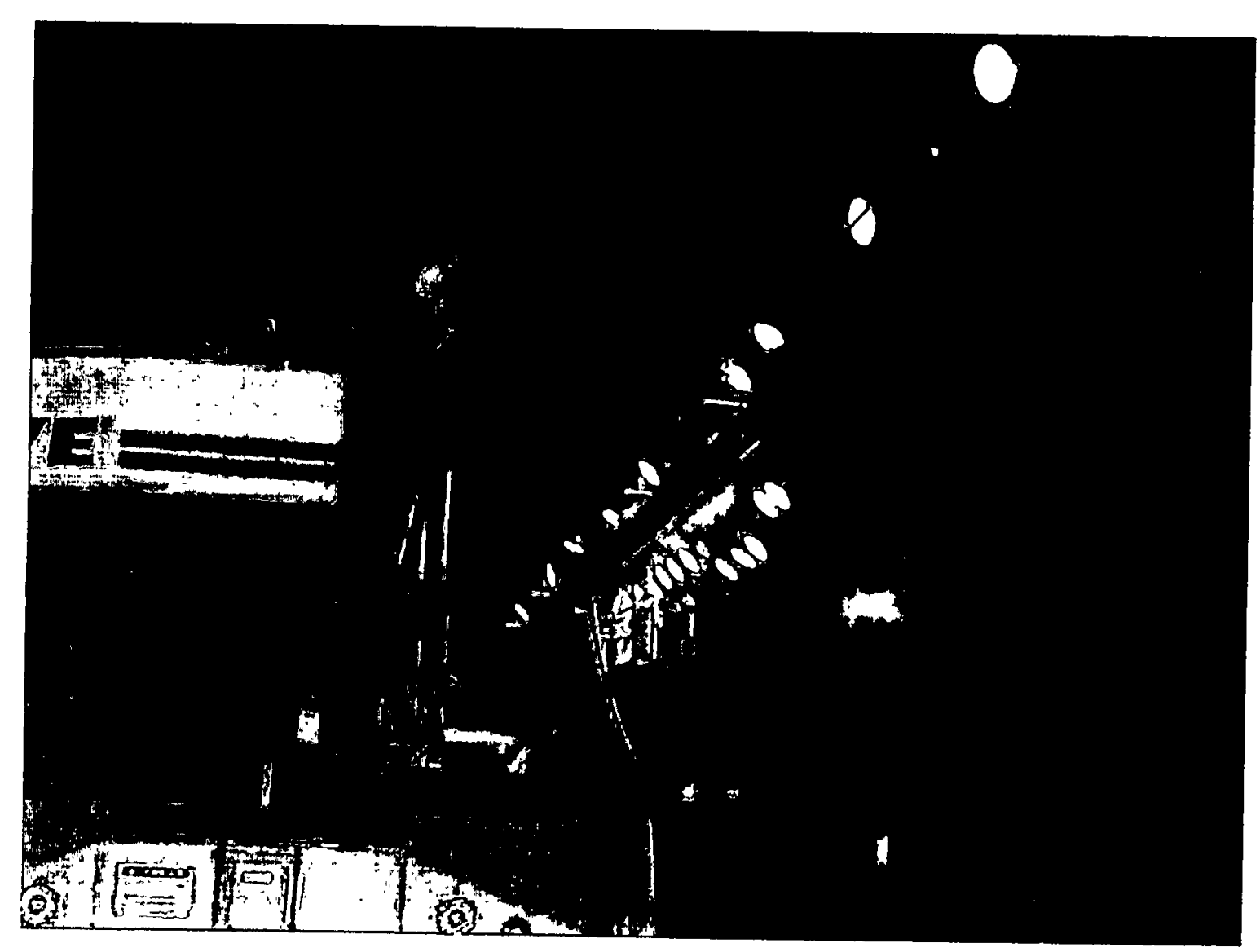

Spray system (on wall). PCBs results were $51.9 \mathrm{ppm}$ in gray paint and $121 \mathrm{ppm}$ in green paint (items disposed). Sample job 98250. 


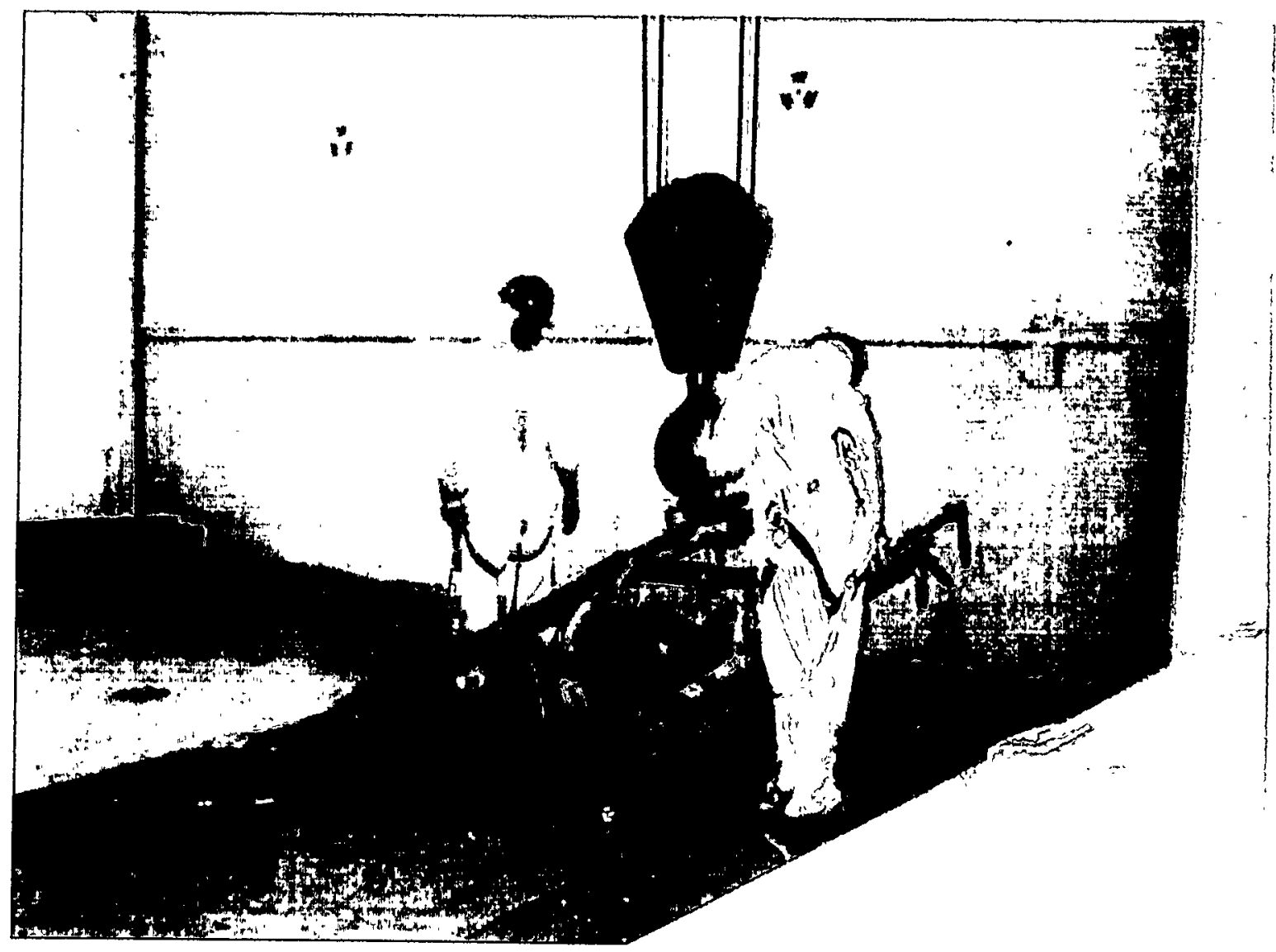

Green paint on spray actuator (121 ppm, item disposed). Sample job 98250. 


\title{
WESTINGHOUSE SAVANNAH RIVER COMPANY
}

\author{
SPENT FUEL STORAGE DIVISION \\ SAMPLE \& ANALYSIS PLAN
}

for the

Characterization of Polychlorinated Biphenyls (PCB) Materials

SFS-RPS-980075

Revision 1

Prepared by

David M. Nichols

Spent Fuel Storage Division

Regulatory Programs Section 


\title{
WESTINGHOUSE SAVANNAH RIVER COMPANY
}

\author{
SPENT FUEL STORAGE DIVISION \\ SAMPLE \& ANALYSIS PLAN
}

for the

\section{Characterization of Polychlorinated Biphenyls (PCB) Materials}

SFS-RPS-980075

Revision 1

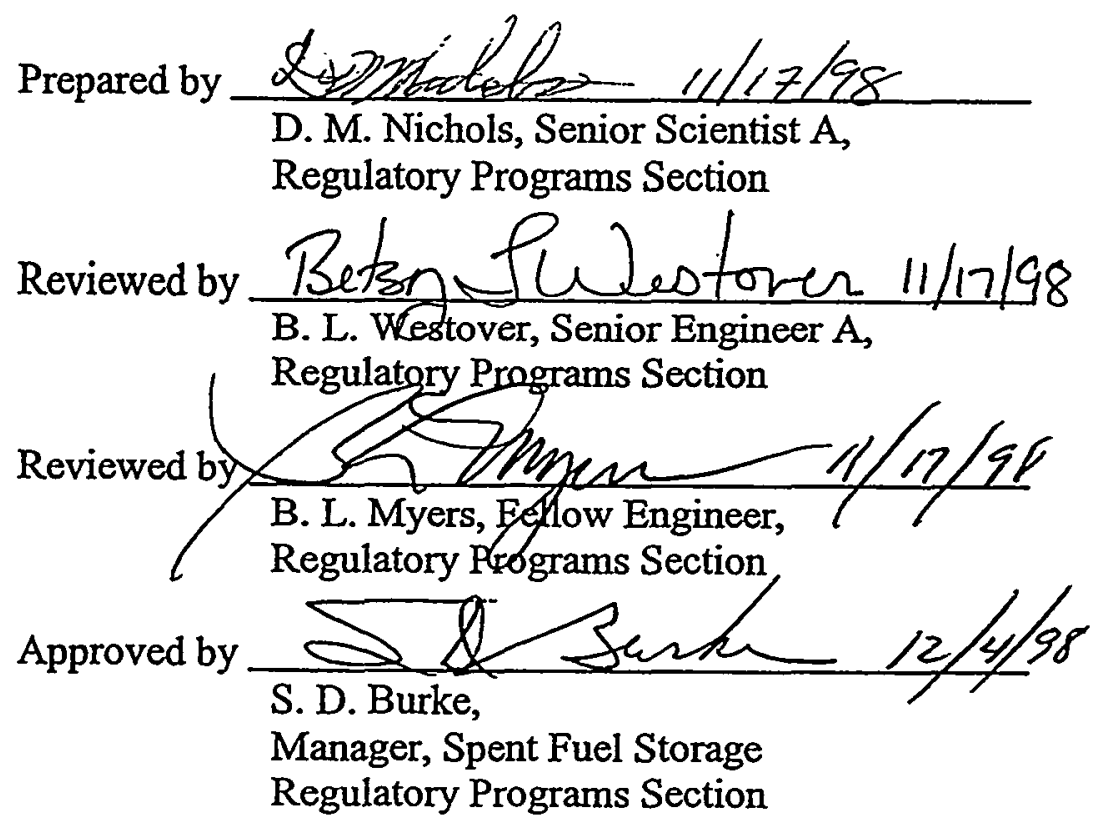




\subsection{INTRODUCTION}

Westinghouse Savannah River Company (WSRC) operates the Savannah River Site (SRS), near Aiken, South Carolina, for the United States Department of Energy (DOE). The nuclear reactors and separations complex at the site produced tritium and other materials to support the U. S. Nuclear Weapons Program.

The Toxic Substances Control Act (TSCA) requires the Environmental Protection Agency (EPA) to regulate disposal and handling of compounds containing Polychlorinated Biphenyls (PCB). TSCA also requires containers of such compounds to be clearly marked and to carry adequate warnings. This Sample and Analysis Plan will provide guidance to permit Spent Fuel Storage Division (SFS) personnel to make an informed decision on the proper handling and disposal of materials removed from SFS facilities.

\subsection{PROJECT DESCRIPTION}

The purpose of this Sample and Analysis Plan (SAP) is to provide data necessary to meet the EPA requirements for the proper disposition of materials that may contain PCBs. This SAP may be used for any material that meets the screening criteria in Attachment 1 .

Due to the limited data on known SRS uses of PCBs in solids other than painted surfaces, any questionable material or equipment should be sampled.

\subsection{TYPE OF MATERIALS}

PCBs have been found in transformers and electrical equipment. PCBs have also been found in materials such as paints, electrical cable, and wire insulation. In addition, PCBs have been found in various other solids such as gaskets, adhesives and certain other types of insulation.

\subsection{DATA QUALITY OBJECTIVES}

The object of the sampling and analysis is to obtain information necessary to complete the Waste Stream Characterization Form for the proper storage of waste. This information will be the basis for acceptance of the waste by Solid Waste Management and provide the necessary information to aid the proper final disposition of the waste. At times, wipe samples may be required to determine PCB leachability from paints.

\subsection{SAMPLE MANAGEMENT}

The samples shall be obtained from each item in question and shall not be combined into a composite sample. If a piece of equipment is painted with several different colors, each color must be sampled separately. 


\subsection{Sample Collection}

Safety must be the first consideration in the selection process. Sampling should be performed under the guidelines of the $3 Q$ Manual, "ECM 6.26, Sampling Containerized Solids", "ECM 6.27 Sampling Containerized Liquids or the Polychlorinated Biphenyls Management Manual, WSRC-IM-95-55. Generally, per analysis, paint samples require a minimum of ten grams, electrical cable a minimum of fifty grams. Disk smears, will require at least five per area. If wipe samples (PCBs only) are required in addition to actual material, they must be obtained first. The material samples should be obtained from an area that will include the area of wipe (per reference 8). The area selected shall be in the best condition (undisturbed, smooth) so as not to bias the results. Complete Attachment 2, Sample Log, for each sample obtained under this Sample and Analysis Plan.

\subsection{Sampling Equipment}

Equipment used to obtain samples is dependent upon the material to be sampled. Disk smear samples are acceptable for surfaces that are covered with oils, such as a lathe or oil cooled drill press. The Sample Management Group will provide the wipe-sampling kits, when required. If further assistance is required, contact Betsy Westover (7-9532) or David Nichols (7-6630).

\subsection{FLELD QUALITY CONTROL}

No field blanks will be taken nor supplied to the laboratory. The laboratory to which the samples will be sent has previously been determined by WSRC representatives from the Procurement Sample Management Program and the Environmental Monitoring Section (EMS) Quality Control to meet SRS QA requirements.

\subsection{REQ̇UIRED ANALYSIS}

The following analysis shall be performed on each sample unless directed by RPS or SFS-Operations Personnel:

- $\quad$ PCB totals

- $\quad$ PCB Wipe

\subsection{ANALYSIS QUALITY CONTROL}

Analysis will be conducted in accordance with EPA-SW-846 methods. The off-site contracted laboratories have quality assurance (QA) programs that meet or exceed the established SRS QA requirements. A scope of work (\#E14593) describing the necessary laboratory qualifications is available in the offices of the Environmental Monitoring Section (EMS). Performance reviews of the laboratories analytical techniques and practices have been completed and are on file with the Quality Control Manager of EMS. The analytical procedures used by the laboratories are also on file in the offices of EMS. 
Laboratory data will be validated prior to use by review against available process knowledge, previous sample analysis, and similar systems or situations.

\subsection{ANALYTICAL RESULTS DISTRIBUTION}

Copies of all laboratory data sheets, analytical data, Attachment 1, and Attachment 2 shall be distributed to the following personnel:

Betsy L. Westover, Senior Engineer A

Room 377, Building 707-C

\subsection{REFERENCES}

1) WSRC 3Q Environmental Compliance Manual, Procedure 21.1, Sample Chain of Custody

2) U. S. Environmental Protection Agency, Test Methods for Evaluating Solid Waste Physical/Chemical Methods (SW-846), Chapter 9 Rev. 0, September, 1986

3) L. H. Keith, Ph.D, Environmental Sampling and Analysis, A Practical Guide, Lewis Publishers, Inc., 1992

4) R. A. Corbitt, Standard Handbook of Environmental Engineering, McGraw-Hill, Inc., 1989

5) WSRC 3Q Environmental Compliance Manual, Procedure 6.26 Sampling Containerized Solids

6) WSRC 1S Manual, Waste Acceptance Criteria

7) Polychlorinated Biphenyls Management Manual, WSRC-IM-95-55.

8) Wipe Sampling and Double Wash/Rinse Cleanup, as recommended by the Environmental Protection Agency, PCB Spill Cleanup Policy, John H. Smith, June 23, 1987, revised April 18,1991 


\section{ATTACHMENT 1}

PCB Evaluation Checklist

Description of item/material:

Painted surface composition (concrete, metal, etc.):

Location of Item:

1. Was the item painted prior to 1982 ? YES NO

2. Was the item known or suspected to be coated with a paint that was specially formulated to have a property of:
a) Waterproofing
b) Fire Resistance
c) Flexibility (temperature changes)
d) Chemical Resistance
e) Abrasion Resistance

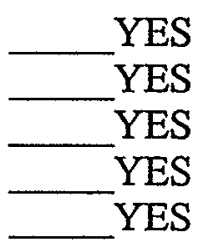
NO NO NO NO NO

3. Is the item known or suspected to be coated with a chlorinated rubber-based paint? YES NO

4. Does the item have orange painted guards? YES NO

5. Was the item used in metalworking (lathe, drill press) or a hydraulic press?

6. Is the item painted structural steel? YES NO

7. Is the paint color
a) Gray
b) Green
c) Blue
d) Orange
e) Yellow
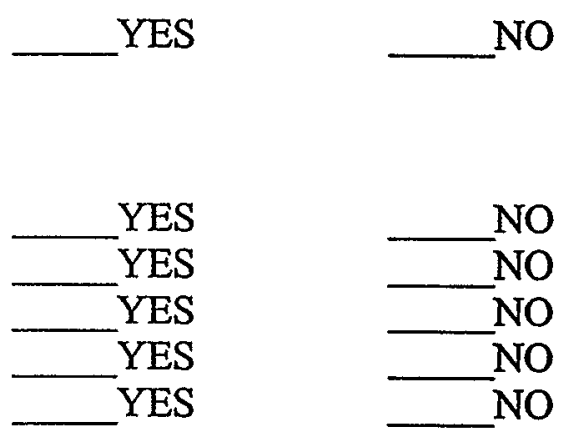

8. Is there a paint specification for this item? Spec. Number

Contact Regulatory Programs Section, Environmental Compliance Group for assistance.

9. If, YES, was selected for questions 1 through 7 contact Regulatory Programs Section, Environmental Compliance Group for assistance. 
WESTINGHOUSE SAVANNAH RIVER COMPANY

Spent Fuel Storage Division

S and A Characterization of PCB Materials
WSRC-TR-99-00194

Enclosure 3

Page 7

SFS-RPS-980075R1

Page:

Nov. 20,1998

\section{ATTACHMENT 2}

Sample Log

\begin{tabular}{|l|l|l|l|}
\hline Sample Number* & Location & Date Sampled & Data Entered by \\
\hline & & & \\
\hline & & & \\
\hline & & & \\
\hline & & & \\
\hline & & & \\
\hline & & & \\
\hline & & + & \\
\hline & & & \\
\hline & & & \\
\hline & & & \\
\hline & & & \\
\hline & & & \\
\hline & & & \\
\hline & & & \\
\hline & & & \\
\hline & & & \\
\hline & & & \\
\hline
\end{tabular}

* Sample Number supplied by Sample Management Group or Regulatory Programs Section

NOTE: 1) If containers (i.e. drums) are sampled, enter container identification number in "Location" column. 


\title{
WESTINGHOUSE SAVANNAH RIVER COMPANY
}

\author{
SPENT FUEL STORAGE DIVISION
}

SAMPLE \& ANALYSIS PLAN

FOR THE

CharaCterization OF POLYChLORINATED BIPHENYLS (PCB)

AND

RESOURCE CONSERVATION AND RECOVERY ACT (RCRA)

MATERIALS

SFS-RPS-980133

Prepared by

David M. Nichols

Spent Fuel Storage Division

Regulatory Programs Section 


\title{
WESTINGHOUSE SAVANNAH RIVER COMPANY
}

\author{
SPENT FUEL STORAGE DIVISION
}

SAMPLE \& ANALYSIS PLAN

FOR THE

CharaCterization OF POLYCHLORINATED BIPHENYLS (PCB)

AND

RESOURCE CONSERVATION AND RECOVERY ACT (RCRA)

MATERIALS

SFS-RPS-980133

Prepared by Eustotutets

D. M. Nichols, Senior Scientist A,

Regulatory Programs Section

Reviewed by Betzy Hevestoren

B. L. Westover, Senior Engineer A,

Regulatory Programs Section

Reviewed by $\frac{\text { M. S. Ellis, Waste Technical Specialist, }}{\text { R }}$

Reactor Waste Management

Approved by $\lesssim$ S

S. D. Burke, Manager,

Spent Fuel Storage

Regulatory Programs Section 


\subsection{INTRODUCTION}

Westinghouse Savannah River Company (WSRC) operates the Savannah River Site (SRS), near Aiken, South Carolina, for the United States Department of Energy (DOE). The nuclear rcactors and separations complex at the site produced tritium and other materials in support of the U. S. Nuclear Weapons Program.

The Toxic Substances Control Act (TSCA) requires the Environmental Protection Agency (EPA) to regulate disposal and handling of compounds containing polychlorinated biphenyls (PCB). TSCA also requires containers of such compounds to be clearly marked and to carry adequate warnings. This Sample and Analysis Plan will provide guidance to permit Spent Fuel Storage Division (SFS) personnel to make an informed decision on the proper handling and disposal of materials removed from SFS facilities.

The Resource Conservation and Recovery Act (RCRA) requires the EPA to regulate the treatment, storage and disposal of materials that have been declared a hazardous waste. Key to the proper handling of the hazardous waste is accurate identification and classification of the waste. This Sample and Analysis Plan will provide guidance to permit SFS personnel to make an informed decision on the proper handling, treatment and/or disposal of materials removed from SFS facilities.

\subsection{PROJECT DESCRIPTION}

The purpose of this Sample and Analysis Plan (SAP) is to provide data necessary to meet the EPA requirements for the proper disposition of materials that may contain PCBs and/or hazardous constituents. This SAP may be used for any material that meets the PCB screening criteria in Attachment 1.

Due to the limited data on known SRS uses of PCBs in solids other than painted surfaces, any questionable material or equipment should be sampled.

\subsection{TYPE OF MATERIALS}

PCBs have been found in transformers and electrical equipment. PCBs have also been found in materials such as paints, electrical cable, and wire insulation. In addition, PCBs have been found in various other solids such as gaskets, adhesives and certain other types of insulation.

While the Site has greater experience in the handling of RCRA waste, the determination of hazardous may be just a difficult. Due to the age of most of the facilities at SRS, most of the paint is lead based. This paint may also have elevated levels of cadmium and chromium. Items as innocent looking as a valve may also contain high levels of lead. 


\subsection{DATA QUALITY OBJECTIVES}

The object of the sampling and analysis is to obtain information necessary to determine suitable waste minimization techniques and treatment alternatives and complete the Waste Stream Characterization Form for the proper storage of waste. This information will be the basis for acceptance of the waste by Solid Waste Management and provide the necessary information to aid the proper final disposition of the waste.

\subsection{SAMPLE MANAGEMENT}

The samples shall be obtained from each item in question and shall not be combined into a composite sample. If a piece of equipment is painted with several different colors, each color must be sampled separately.

\subsection{Sample Collection}

Safety must be the first consideration in the selection process. Sampling should be performed under the guidelines of the $3 Q$ Manual, "ECM 6.26, Sampling Containerized Solids", "ECM 6.27 Sampling Containerized Liquids" or the Polychlorinated Biphenyls Management Manual, WSRC-IM-95-55. Sample volumes will be determined by the analysis required and provided by the Sample Management Group.

Generally, per analysis, paint samples require a minimum of ten grams, electrical cable a minimum of fifty grams. If wipe samples (PCBs only) are required in addition to actual material, they must be obtained first. The material samples should be obtained from an area that will include the area of wipe (per reference 8). The area selected shall be in the best condition (undisturbed, smooth) so as not to bias the results. Complete Attachment 2, Sample Log, for each sample obtained under this Sample and Analysis Plan.

\subsection{Sampling Equipment}

Equipment used to obtain samples is dependent upon the material to be sampled. Disk smear samples are acceptable for surfaces that are covered with oils, such as a lathe or oil cooled drill press. The Sample Management Group will provide the wipe-sampling kits, when required. If further assistance is required, contact Betsy Westover (7-9532) or David Nichols (7-6630).

\subsection{FIELD QUALITY CONTROL}

No field blanks will be taken nor supplied to the laboratory. The laboratory to which the samples will be sent has previously been determined by WSRC representatives from the Procurement Sample Management Program and the Environmental Monitoring section (EMS) Quality Control to meet SRS QA requirements. 


\subsection{REQUIRED ANALYSIS}

The following analysis shall be performed on each sample unless directed by Regulatory Program Section or SFS-Operations Personnel:

- $\quad$ PCB Totals

- $\quad$ PCB - TCLP

- RCRA Metals - Totals

- $\quad$ RCRA Metals - TCLP

\subsection{ANALYSIS QUALITY CONTROL}

Analysis will be conducted in accordance with EPA-SW-846 methods. The off-site contracted laboratories have quality assurance (QA) programs that meet or exceed the established SRS QA requirements. A scope of work (\#E14593) describing the necessary laboratory qualifications is available in the offices of the Environmental Monitoring Section (EMS). Performance reviews of the laboratories analytical techniques and practices have been completed and are on file with the Quality Control Manager of EMS. The analytical procedures used by the laboratories are also on file in the offices of EMS.

Laboratory data will be validated prior to use by review against available process knowledge, previous sample analysis, and similar systems or situations.

\subsection{ANALYTICAL RESULTS DISTRIBUTION}

Copies of all laboratory data sheets, analytical data, Attachment 1, and Attachment 2 shall be distributed to the following personnel:

Betsy L. Westover, Senior Engineer A Environmental Compliance Group Room 377, Building 707-C

David M. Nichols, Senior Scientist A Environmental Compliance Group Room 378, Building 707-C 
WESTINGHOUSE SAVANNAH RIVER COMPANY

Spent Fuel Storage Division

$\underline{S}$ and $A$ Characterization of PCB/RCRA Materials

\subsection{REFERENCES}

1) WSRC 3Q Environmental Compliance Manual, Procedure 21.1, Sample Chain of Custody

2) U. S. Environmental Protection Agency, Test Methods for Evaluating Solid Waste Physical/Chemical Methods (SW-846), Chapter 9 Rev. 0, September, 1986

3) L. H. Keith, Ph.D, Environmental Sampling and Analysis, A Practical Guide, Lewis Publishers, Inc., 1992

4) R. A. Corbitt, Standard Handbook of Environmental Engineering, McGraw-Hill, Inc., 1989

5) WSRC 3Q Environmental Compliance Manual, Procedure 6.26, Sampling Containerized Solids

6) WSRC 1S Manual, Waste Acceptance Criteria

7) Polychlorinated Biphenyls Management Manual, WSRC-IM-95-55

8) Wipe Sampling and Double Wash/Rinse Cleanup, as recommended by the Environmental Protection Agency, PCB Spill Cleanup Policy, John H. Smith, June 23, 1987, revised April 18,1991 


\section{ATTACHMENT 1}

PCB Evaluation Checklist

Description of item/material:

Painted surface composition (concrete, metal, etc.):

Location of Item:

1. Was the item painted prior to 1982 ? YES NO

2. Was the item known or suspected to be coated with a paint that was specially formulated to have a property of:
a) Waterproofing
b) Fire Resistance
c) Flexibility (temperature changes)
d) Chemical Resistance
e) Abrasion Resistance
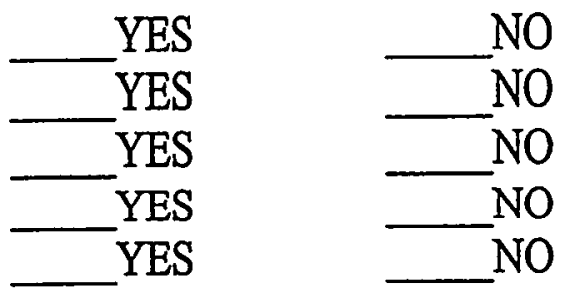

3. Is the item known or suspected to be coated with a chlorinated rubber-based paint? YES NO

4. Does the item have orange painted guards?

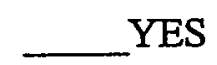
NO

5. Was the item used in metalworking (lathe, drill press) or a hydraulic press?

6. Is the item painted structural steel? YES NO 7. Is the paint color
a) Gray
b) Green
c) Blue
d) Orange
e) Yellow

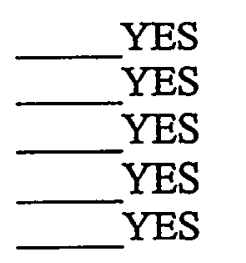
NO NO NO NO NO

8. Is there a paint specification for this item? Spec. Number Contact Regulatory Programs Section, Environmental Compliance Group for assistance.

9. If, YES, was selected for questions 1 through 7 contact Regulatory Programs Section, Environmental Compliance Group for assistance. 
WESTINGHOUSE SAVANNAH RIVER COMPANY

Spent Fuel Storage Division

S and A Characterization of PCB/RCRA Materials
WSRC-TR-99-00194

Enclosure 4

Page 8

SFS-RPS-980133

Page: 8 of 8

Nov. 13,1998

\section{ATTACHMENT 2}

\section{Sample Log}

\begin{tabular}{|l|l|l|l|}
\hline Samplc Numbcr* & Location & Date Sampled & Data Entered by \\
\hline \hline & & & \\
\hline & & & \\
\hline & & & \\
\hline & & & \\
\hline & & & \\
\hline & & & \\
\hline & & & \\
\hline & & & \\
\hline & & & \\
\hline & & & \\
\hline & & & \\
\hline & & & \\
\hline & & & \\
\hline & & & \\
\hline & & & \\
\hline & & & \\
\hline & & & \\
\hline
\end{tabular}

* Sample Number supplied by Sample Management Group or Regulatory Programs Section

NOTE: 1) If containers (i.e. drums) are sampled, enter container identification number in "Location" column.

Comments: (list by Sample Number) 